\title{
The complexity of NF-KB signaling in inflammation and cancer
}

\author{
Bastian Hoesel and Johannes A Schmid ${ }^{*}$
}

\begin{abstract}
The NF-KB family of transcription factors has an essential role in inflammation and innate immunity. Furthermore, $\mathrm{NF}-\mathrm{KB}$ is increasingly recognized as a crucial player in many steps of cancer initiation and progression. During these latter processes NF-KB cooperates with multiple other signaling molecules and pathways. Prominent nodes of crosstalk are mediated by other transcription factors such as STAT3 and p53 or the ETS related gene ERG. These transcription factors either directly interact with NF-kB subunits or affect NF-kB target genes. Crosstalk can also occur through different kinases, such as GSK3- $\beta$, p38, or PI3K, which modulate NF-KB transcriptional activity or affect upstream signaling pathways. Other classes of molecules that act as nodes of crosstalk are reactive oxygen species and miRNAs. In this review, we provide an overview of the most relevant modes of crosstalk and cooperativity between NF-KB and other signaling molecules during inflammation and cancer.
\end{abstract}

Keywords: NF-kappa B signaling, Cancer, Inflammation, Cooperativity, Crosstalk

\section{Introduction}

The transcription factor NF-kB was discovered in 1986 as a nuclear factor that binds to the enhancer element of the immunoglobulin kappa light-chain of activated B cells (thereby coining the abbreviation NF-kB) [1]. Soon afterwards it became clear that proteins, which harbor this specific DNA binding activity are expressed in nearly all cell types and regulate many target genes with a whole variety of functions [2]. In total, five members of this transcription factor family have been identified, designated as p65 (RelA), RelB, c-Rel, NF-kB1 and NF-kB2 (Figure 1A). In contrast to the other family members, NF- $k B 1$ and NF$\kappa \mathrm{B} 2$ are synthesized as pro-forms (p105 and p100) and are proteolytically processed to p50 and p52 (Figure 1A, black arrows), respectively [3]. All five members of this protein family form homo- or heterodimers and share some structural features, including a Rel homology domain (RHD), which is essential for dimerization as well as binding to cognate DNA elements [4]. In most quiescent cells these dimers are bound to inhibitory molecules of the I $\kappa$ B family of proteins (inhibitors of NF-kB) (Figure 1B). These inhibitors are characterized by ankyrin repeats, which associate

\footnotetext{
* Correspondence: johannes.schmid@meduniwien.ac.at Department of Vascular Biology and Thrombosis Research, Center for Physiology and Pharmacology, Medical University Vienna, Schwarzspanierstraße 17, 1090 Vienna, Austria
}

with the DNA-binding domains of the transcription factors thereby making them transcriptionally inactive. Interestingly, p105 and p100, the precursors of p50 and p52, also contain ankyrin repeats, which are cleaved upon maturation - thus comprising their own internal inhibitors. In contrast to the other members of the NF- $\mathrm{kB}$ family these two proteins do not contain a transactivation domain [5]. As a consequence, dimers of p50 and p52, which bind to NF- $\mathrm{kB}$ elements of gene promoters, act as transcriptional repressors [6]. However, when p50 or p52 are bound to a member containing a transactivation domain, such as p65 or RelB, they constitute a transcriptional activator. Another interesting aspect is that one member of the IKB family, Bcl-3, also contains transactivation domains (Figure 1B) and can bind to dimers of p50 and p52 rendering the complex transcriptionally active [7-9]. The complexity of this transcriptional regulation system is also augmented by the fact that different NF- $\mathrm{KB}$ dimers have differential preferences for variations of the DNA-binding sequence [10]. Thus different target genes are differentially induced by distinct NF- $\mathrm{kB}$ dimers. Furthermore, NF- $\mathrm{KB}$ subunits also contain sites for phosphorylations and other post-translational modifications which are important for activation and crosstalk with other signaling pathways [11]. Binding of NF- $\kappa B$ dimers to ІкB molecules does not only prevent binding to DNA, but also shifts the steady- 


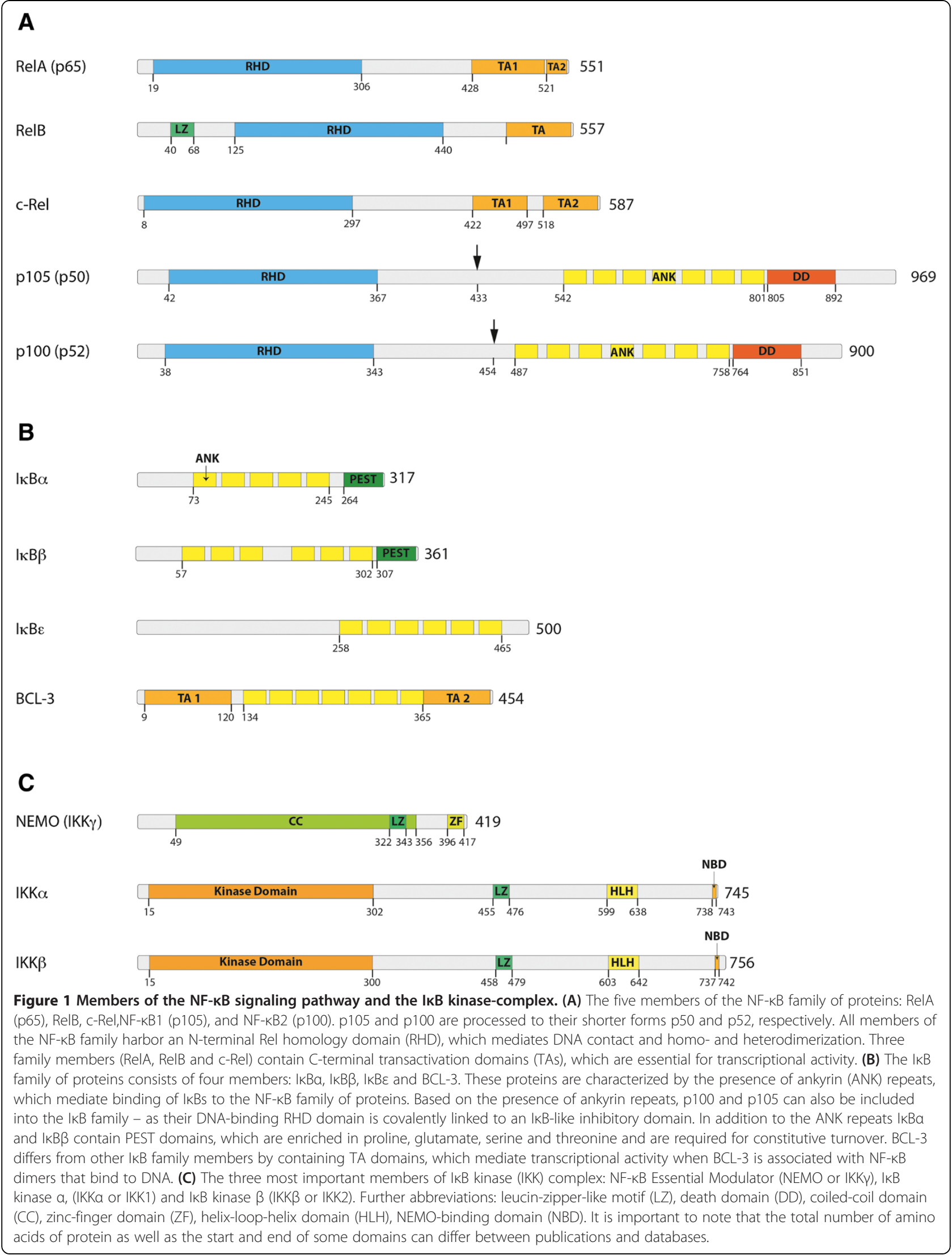


state localization of the complex to the cytosol. Nevertheless, shuttling between cytosol and nucleus does occur $[12,13]$, which might be a basis for a low basal transcriptional activity of NF- $\mathrm{kB}$ given that the $\mathrm{I} \kappa \mathrm{B} / \mathrm{NF}-\kappa \mathrm{B}$ complex is subject to dissociation and re-association processes.

\section{Signaling pathways activating NF-кB}

In general, activation of NF- $\mathrm{kB}$ occurs by release from the I $\mathrm{B}$ molecules or by cleavage of the inhibitory ankyrin repeat domains of p100 and p105. This is achieved by proteasomal degradation of the inhibitors or by partial degradation of the precursors. A prerequisite for the degradation is polyubiquitination of the target molecules with lysine-48 linked ubiquitin chains, which is catalyzed by $\mathrm{SCF}^{\beta \operatorname{TrCP}}$ type E3-ligases. These ubiquitination enzymes require a specific double phosphorylation on the substrate as recognition site. The latter is catalyzed by an enzyme complex containing IKB kinases (IKK1/IKK $\alpha$ and IKK2/IKK $\beta$ ) and at least one non-catalytic accessory protein (NF-kB Essential Modulator, NEMO or also termed IKK $\gamma$ ) [14-16]. This ІкB kinase or IKK-complex binds to additional components and interacts with upstream signaling molecules and kinases. A great variety of stimuli can activate the IKK complex by different mechanisms including phosphorylation of the activation loop of IKK's (S177 and S181 of IKK2, [17]) by upstream kinases or via proximityinduced self-activation of IKK-dimers by mutual transphosphorylation [18]. Kinases that mediate phosphorylation and activation of IKKs include the NF- $\mathrm{kB}$ inducing kinase NIK, which predominantly phosphorylates IKK1 on S176 $[19,20]$, as well as MEKK1, MEKK2, MEKK3 and TGF- $\beta$ activating kinase 1 (TAK1) [21-23]. TAK1 is a member of a larger protein kinase complex, which consists of TAK1, TAB1 and TAB2 and can phosphorylate IKK2 as well as NIK $[23,24]$. MEKK3 is a member of the MAP3K family and is known to have a role in TLR4 mediated signaling [25]. Furthermore it seems that TAK1 and MEKK3 have differential roles in interleukin and Toll-like receptor mediated NF- $\mathrm{B}$ activation [25,26]. Lysine-63 linked polyubiquitin chains attached to signaling molecules by RINGtype E3 ligases (such as TRAF2 or TRAF6) have been demonstrated to act as activation platform [27,28], as well as linear polyubiquitination of upstream effector molecules $[29,30]$. These various activation mechanisms guarantee that all different stress situations can induce the catalytic activity of IKKs thereby leading to the liberation and activation of the general stress response factor NF-kB. In addition, they provide a basis for manifold crosstalk with other signaling pathways, as well as complex feedback circuits allowing for a fine-tuning of the response. Since K63-linked or linear polyubiquitination provide mechanisms for activation of the NF- $\mathrm{B}$ pathway it is plausible that several of the feedback inhibitors represent deubiquitinases (DUB's) such as A20 [31] or CYLD [32].
In the canonical activation pathway (Figure 2A), excitatory signaling can be mediated through Toll-like receptors (TLRs), Interleukin-1 receptor (IL-1R), tumor necrosis factor receptor (TNFR) and antigen receptors. Typical stimulating signaling molecules are tumor necrosis factor $\alpha$ (TNF $\alpha)$, lipopolysaccharides (LPS), which are bacterial cell wall components, and interleukin-1 $\beta$ (IL-1 $\beta$ ) [18,33]. Stimulation through these receptors leads to activation of the IкB kinase (IKK) complex, which in turn phosphorylates $\mathrm{I} \kappa \mathrm{B} \alpha$ primarily by IKK 2 .

An alternative pathway of NF- $\kappa B$ activation, also designated as non-canonical pathway [34] (Figure 2B) originates from different classes of receptors including B-cell activation factor (BAFFR), lymphotoxin $\beta$-receptor (LT $\beta R), C D 40$, receptor activator for nuclear factor kappa B (RANK), TNFR2 and Fn14 [35]. These lead to activation of the NF- $\mathrm{B}$ inducing kinase NIK, which phosphorylates and activates predominantly IKK 1 . The activity of the latter enzyme induces phosphorylation of p100 resulting in its ubiquitination and partial degradation to p52 [36]. The mechanisms leading to activation of the non-canonical pathway are thus independent of the activity of IKK2 and NEMO [37].

In many cases, p100 is associated with RelB, so that its proteolytic processing induces the formation of a transcriptionally active RelB/p52-complex [38,39]. Besides the canonical and the alternative pathway, additional pathways of NF- $\mathrm{KB}$ activation exist, sometimes termed atypical activation pathways (Figure $2 \mathrm{C}$ ). One of these is activation of the IKK complex after genotoxic stress via the kinase ATM leading to ubiquitination of NEMO [40]. Others involve tyrosine kinases or casein kinase 2 [41-43]. The epidermal growth factor receptor (EGFR) tyrosine kinase has for example been shown to promote NF- $\mathrm{kB}$ dependent transcription in ovarian cancer [44].

After the liberation of various NF- $\mathrm{kB}$ dimers following activation of IKKs, their steady state localization is normally shifted to the nucleus and the Rel Homology Domains are free to bind cognate DNA-sequences in the enhancer elements of target gene promoters. Depending on the accessibility of the genome regulated by epigenetic mechanisms and the cell type, thousands of different target genes can be transcriptionally activated. This activation is further controlled by additional transcription factors, which can either enhance or reduce the effect of NF- $\mathrm{kB}-$ establishing another level of complexity and crosstalk with signaling pathways that activate other transcription factors. The manifold post-translation modifications of RelA add another layer of complexity to NF- $\mathrm{kB}$ signaling. These have been shown to be necessary for various aspects of RelA functions (Figure 3). Amongst these, phosphorylations at specific serine or threonine residue are known to be particularly important since they often stimulate transcriptional activity. The most important phosphorylations 


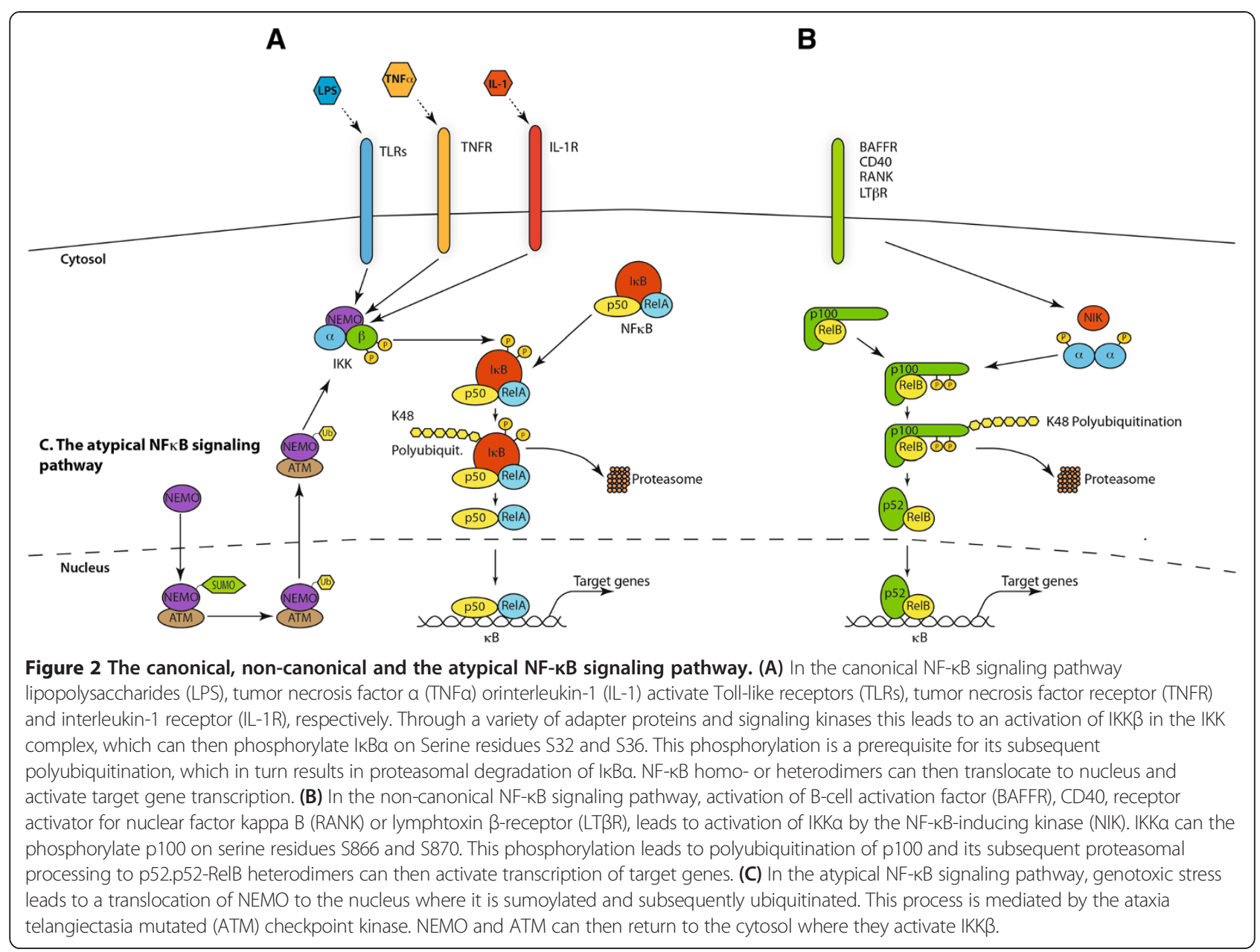

of RelA, their positions and the corresponding kinases are summarized in Table 1 . The activity of NF-kB is not only influenced by a variety of phosphorylations, but also by dynamic and complex protein-protein interactions generating a sophisticated network of interdependencies and feedback loops [45]. Besides the very well defined interactions between the various members of the NF-kB family, and the interactions with their inhibitors such as $\mathrm{I} \kappa \mathrm{B} \alpha$,

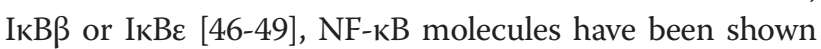
to interact with upstream kinases, with chromatinmodifiers such as histone deacetylases (HDACs), p300 or CBP and also with other transcription factors [50-53]. The network of protein interactions involving NF- $\mathrm{KB}$ molecules is very complex. The interaction database IntAct (http://www.ebi.ac.uk/intact/) currently lists 306 binary interactions for the NF-kB member RelA alone. To illustrate at least part of this interaction network graphically, we performed a STRING database search (at http://string$\mathrm{db} . o r g /)$ for proteins interacting either physically or functionally with NF-kB molecules using all five family members as input (Figure 4).
Termination of the transcriptional activity of NF- $\mathrm{kB}$ is mainly achieved by the fact that NF- $\mathrm{kB}$ up-regulates its own inhibitors of the IкB family, where the best studied ex-

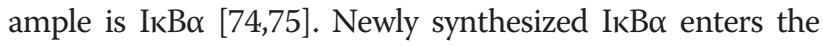
nucleus, removes NF- $\mathrm{kB}$ from the DNA and relocates it to the cytosol [11]. In addition, negative regulators of the NF$\mathrm{\kappa B}$ signaling pathway such as A20 [31] and CYLD [32] are up-regulated by NF- $\mathrm{kB}$. In acute inflammation, these negative feedback loops usually result in complete de-activation of NF- $\mathrm{KB}$ to the normal background level. However, in chronic inflammatory conditions, the persistent presence of NF- $\mathrm{KB}$ activating stimuli seems to outperform the inhibitory feedback circuits leading to an elevated constitutive activity of NF-kB.

\section{The NF-KB signaling pathway in inflammation and cancer}

Inflammation is the process of innate immunity in response to physical, physiological and/or oxidative stress and is associated with activation of the canonical NF- $\mathrm{kB}$ signaling pathway, which is conserved in all multicellular 


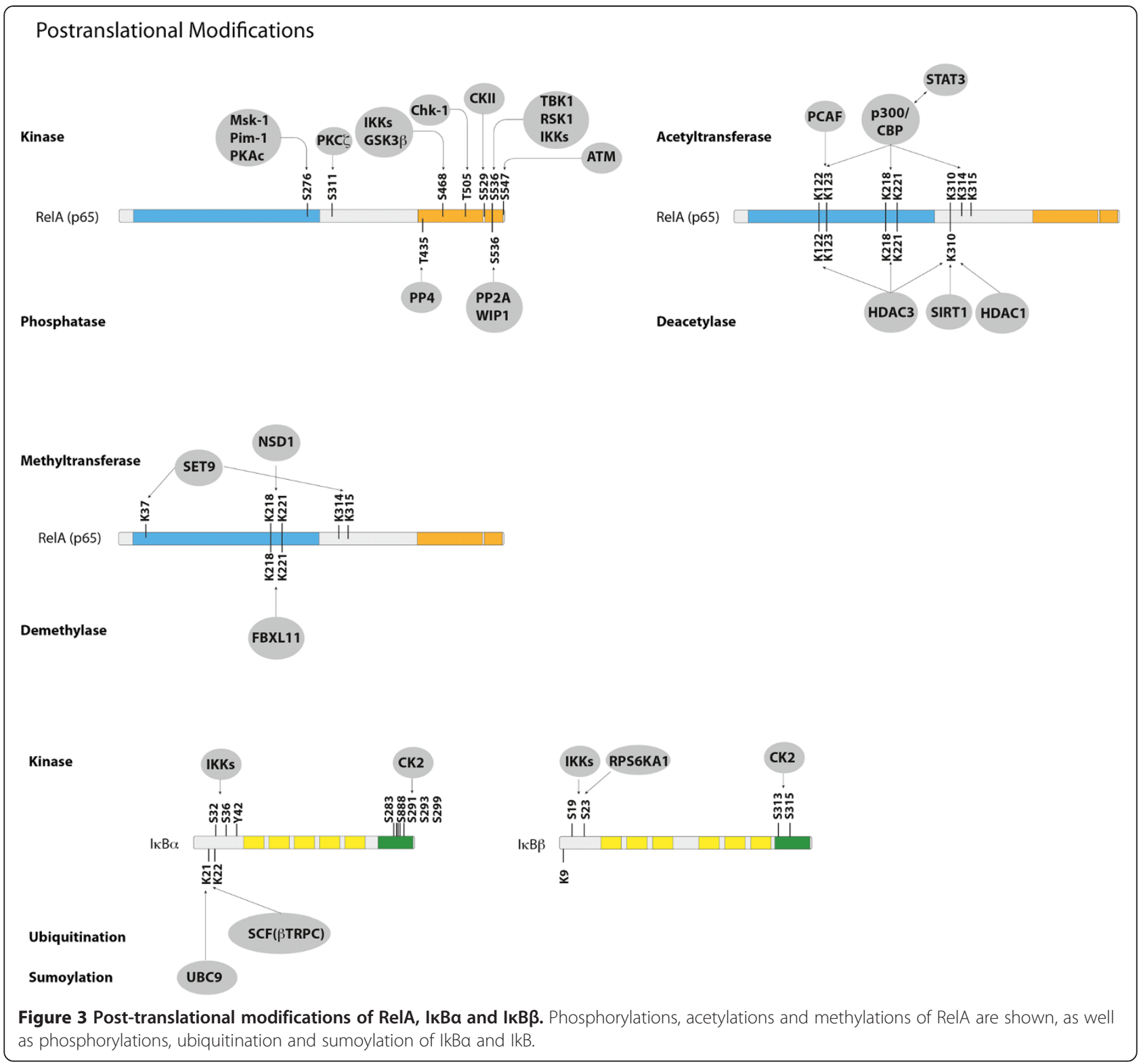

animals [76]. Inflammation in general and NF- $\mathrm{BB}$ in particular have a double-edged role in cancer. On one hand, activation of NF- $\mathrm{KB}$ is part of the immune defense, which targets and eliminates transformed cells. This seems to be particularly true for acute inflammatory processes, where full activation of NF- $\mathrm{kB}$ is accompanied by a high activity of cytotoxic immune cells against cancer cells [77]. On the other hand, NF- $\mathrm{kB}$ is constitutively activated in many types of cancer and can exert a variety of pro-tumorigenic functions. The effectiveness of the immune system against malignant cells has been unveiled by the observation that pharmacologically immune-suppressed individuals, e.g. after organ transplantations, have a higher cancer risk. This anti-tumorigenic function of the immune systems with NF-kB being an important effector of it, has been designated as tumor-immunosurveillance [78]. This immune defense against cancer cells, however, is normally not tight enough to eliminate all the aberrant cells, resulting in a shift to an equilibrium phase, which is often followed by an "escape" phase of the cancer cells, in which they outperform the immune system [79]. The latter two phases seem to be characterized by a chronic inflammatory condition with often only moderately elevated levels of NF- $k B$ activity. The notion that such a constitutive activity of NF- $\kappa B$ exerts a pro-tumorigenic effect is underscored by the observation that patients with chronic inflammatory diseases have higher risks for cancer similar to immunesuppressed patients (see accompanying article). NF-kB activation usually results in the up-regulation of antiapoptotic genes thereby providing cell survival mechanism 
Table 1 Positions of Phosphorylations of RelA and corresponding kinases

\begin{tabular}{|c|c|c|c|}
\hline Kinase & p65 target residue & Effect of phosphate & References \\
\hline unknown & S205 & stimulates transcriptional activity & [54] \\
\hline MSK1 & S276 & stimulates transcriptional activity & [55] \\
\hline PIM1 & S276 & stimulates transcriptional activity & [56] \\
\hline PKAC & S276 & stimulates transcriptional activity & {$[57,58]$} \\
\hline unknown & S281 & stimulates transcriptional activity & [54] \\
\hline PKC & S311 & stimulates transcriptional activity & [59] \\
\hline GSK-3 $\beta$ & S468 & stimulates transcriptional activity & {$[60]$} \\
\hline IKK2 & S468; S536 & stimulates transcriptional activity and nuclear import & {$[61,62]$} \\
\hline IKK $\varepsilon$ & S468;S536 & stimulates transcriptional activity & {$[63,64]$} \\
\hline CKII & S529 & stimulates transcriptional activity & [65] \\
\hline CaMKIV & S535 & stimulates transcriptional activity & [66] \\
\hline TBK1 & S536 & stimulates transcriptional activity & {$[67]$} \\
\hline IKK1 & S536 & stimulates transcriptional activity and stabilization & [68] \\
\hline RSK1 & S536 & decreases ІкВа -mediated nuclear export & [69] \\
\hline ATM & S547 & Increased expression of specific genes & [70] \\
\hline unknown & T254 & stabilization and nuclear localization & [71] \\
\hline unknown & T435 & stimulates transcriptional activity & [72] \\
\hline CHK1 & T505 & pro-apoptotic effect & [73] \\
\hline
\end{tabular}

to withstand the physiological stress that triggered the inflammatory response. Furthermore, NF-кB induces cytokines that regulate the immune response (such as TNF $\alpha$, IL-1, IL-6 and IL-8), as well as adhesion molecules, which lead to the recruitment of leukocytes to sites of inflammation. In addition to its role in innate immunity NF- $\mathrm{kB}$ signaling was shown to control a great variety of other well conserved cellular processes, including cell proliferation $[80,81]$ and apoptosis [82]. The contribution of inflammation in general and NF- $\mathrm{kB}$ in particular to cancer initiation and progression is manifold and complex. It is postulated that the innate immune response of neutrophils that release reactive oxygen species to kill invading pathogens might cause DNA-damage and thus genetic mutations as side effects, thereby triggering tumor initiation [83]. Moreover, NF-kB signaling was shown to contribute to cancer progression by controlling epithelial to mesenchymal transition and metastasis [84]. The latter is often associated with an up-regulation of matrix metalloproteinases (MMPs), loosening the extracellular matrix for an evasion of cancer cells. Finally, NF- $\mathrm{kB}$ can also contribute to tumor progression by controlling vascularization of tumors via upregulation of VEGF (vascular endothelial growth factor) and its receptors $[85,86]$.

A tumor can principally establish elevated NF- $\mathrm{kB}$ activity by intrinsic or extrinsic factors [87]. On the one hand, enhanced NF- $\mathrm{kB}$ activity can be directly induced by mutations of NF-kB genes and/or oncogenes that activate the NF- $\mathrm{BB}$ signaling pathway. On the other hand, a tumor can achieve elevated NF- $\mathrm{kB}$ activity through increased cytokine release from the tumor microenvironment [76].

Direct mutations of NF-kB signaling genes have so far been detected mainly in lymphoid malignancies. Amplification and point mutations of RelA were detected in human B-cell lymphomas such as Hodgkin lymphoma and to a lower extent also in T-cell lymphomas, reflecting the direct oncogenic potential of the NF-kB signaling pathway which was suggested since the initial discovery of the oncogenic RelA homologue v-Rel [88]. Furthermore, chromosomal truncations of the NFKB2 gene have been detected in certain lymphomas $[89,90]$. Moreover, mutations of other members of the NF-kB signaling pathway including Bcl-3 and c-Rel have been detected in B-cell leukemia and several types of B-cell lymphomas, respectively [91-94].

In solid tumors, in contrast, direct mutations of the NF$\mathrm{\kappa B}$ signaling pathway are rare events [95]. Nevertheless, they do occur, as exemplified by a recently discovered gene fusion between IKK2 and TNPO1 (transportin 1), which resulted in elevated IKK2 expression levels in prostate cancer [96]. Furthermore, a recent study on breast cancer revealed mutations in NFKB1, the upstream kinase $\mathrm{IKK} 2$, as well as the inhibitors $\mathrm{I} K \mathrm{~B} \alpha$ and $\mathrm{I} \kappa \mathrm{B} \varepsilon$ [97]. Studies with transgenic mice suggest a direct contribution of the NF- $\mathrm{kB}$ signaling pathway to the development of various solid tumors. The maybe best-studied example is inflammation associated colon cancer, where IKK2-induced NF$\mathrm{kB}$ within intestinal epithelial cells has an essential role for tumor formation. Furthermore, IKK2-mediated NF- $\mathrm{KB}$ activity within myeloid cells of the tumor environment 
contributes to tumor progression by inducing the secretion of cytokines and growth factors [98]. A different inflammation-associated type of cancer is hepatocellular carcinoma, a form of liver cancer, which can occur after viral hepatitis or after liver damage induced by carcinogenic substances. Interestingly, the role of NF-kB in liver cancer seems to depend very much on the precise mechanism of cancer development. Tumors associated with chronic inflammation seem to require NF- $\mathrm{kB}$ within hepatocytes as anti-apoptotic survival factor. However, in certain types of chemically induced liver cancer, hepatocytic NF- $\mathrm{kB}$ in contrary acts as tumor suppressor as shown by mouse studies with hepatocyte-specific deletion of IKK2 or NEMO and treatment with diethylnitrosamine (DEN) as carcinogen [99]. Nevertheless, this type of cancer still requires NF- $\mathrm{kB}$ within Kupffer cells (the resident macrophages of the liver), which is essential for secretion of IL-6 and activation of STAT3 in neighboring hepatocytes. Thus, the cellular location of NF-kB activity is fundamental for the development of liver cancer. Another cancer that depends on NF-kB activity is melanoma, as it could be shown that HRas-mediated initiation of tumorigenesis requires IKK2-mediated NF- $\mathrm{kB}$ activation in a mouse model of melanoma [100] and even for lung cancer it could be demonstrated that IKK2 and NF-KB are crucial cofactors [101]. In general, aberrant NF- $k B$ activity seems to have an important role as co-factor in solid tumors by acting as survival factor for transformed cells, which

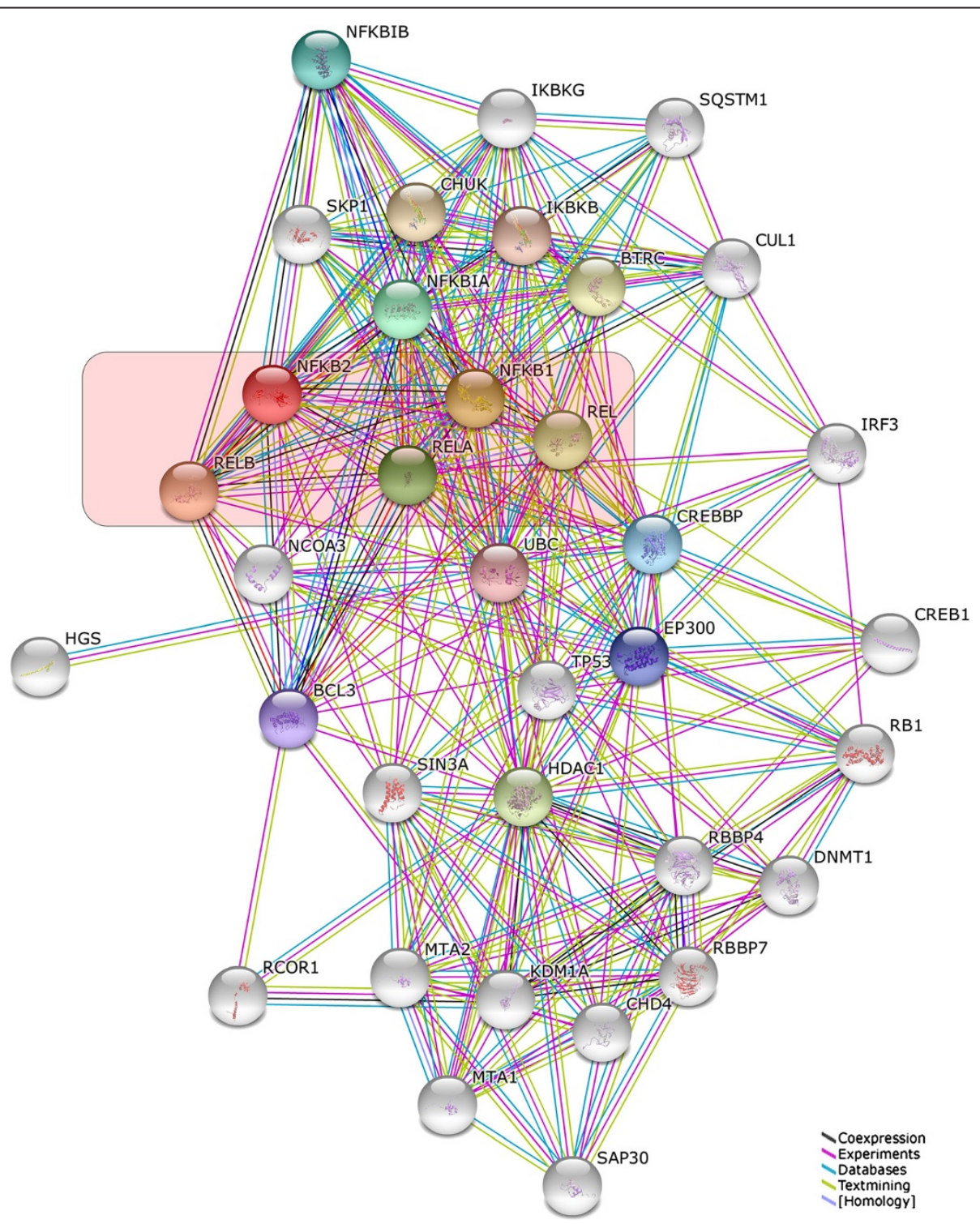

Figure 4 Network of NF-KB interactors. Evidence view of the STRING database output depicting functional and physical interactors of the NF-KB proteins, RelA, Rel (c-Rel), RelB, NFKB1 and NFKB2 obtained from: http://string-db.org/. The five NF-KB proteins are highlighted in red. 
would otherwise become apoptotic or senescent. This elevated constitutive NF- $\mathrm{kB}$ activity is usually achieved through continuous release of cytokines by macrophages in the tumor microenvironment. However, there is still a mystery in the crosstalk between solid tumors and neighboring macrophages: While most tumors are characterized by elevated levels of cytokines released by classically (M1)-activated macrophages, such as TNF $\alpha$ and IL-1 $\beta$, the macrophages in the tumor microenvironment seem to switch to the M2-phenotype, the so-called alternatively activated form, which seems to be the predominant form of tumor-associated macrophages (TAMs) - releasing rather anti-inflammatory cytokines. IKK2 and NF- $\mathrm{kB}$ apparently polarize macrophages towards the alternatively activated M2 phenotype, which tolerates and even fosters the tumor instead of attacking it [102]. It seems possible, that the timing is crucial for the crosstalk between tumor cells and macrophages. An initial inflammatory environment triggered by the tumor might induce the secretion of TNF $\alpha$ and IL-1 $\beta$ from resident macrophages, whereas prolonged tumor growth and chronic inflammation might lead to a shift towards tumor-associated, M2-type macrophages - a notion that is also in line with the concept that tumors are interpreted by the organism often as "wounds that do not heal" [103]. In addition to the role of NF-kB for survival of cancer cells or the response of immune cells to cancer, NF$\kappa \mathrm{B}$ has recently been shown to be activated in cancer stem cells (CSCs), where it can promote a pro-inflammatory environment, inhibit apoptosis and stimulate cellproliferation. Cancer stem cells comprise only a minor subpopulation of cancer cells and are thought to mediate tumor growth and resistance to chemotherapy [104,105].

\section{Crosstalk of NF-KB with other transcription factors}

In general, transcription factors can exert mutual influences by a variety of mechanisms. One of them is direct physical association, which can influence transcriptional activity or DNA-binding. Direct binding to NF- $\kappa B$ is known for several transcription factors including STAT3, p53, estrogen receptor, ATF3, SMAD3 and 4 (according to the IntAct database). Furthermore, transcription factors often bind in close vicinity to each other on their cognate sequences of promoter or enhancer elements thereby facilitating the recruitment of components of the transcriptional machinery. In this way, they can either enhance or repress the function of another transcription factor [106]. Functional links between NF- $\mathrm{kB}$ and other transcription factors are therefore manifold - depending on the promoter structure of target genes. Several of these links have been studied and characterized in more detail, in particular those with STAT family members (signal transducers and activators of transcription) and with the p53 tumor suppressor $[107,108]$.
$\mathrm{NF}-\mathrm{\kappa B}$ and STAT3 cooperatively regulate a number of target genes including anti-apoptotic as well cycle control genes. Moreover, they also synergistically control a common set of genes encoding for cytokines and chemokines $[109,110]$. It has been shown that p65 and p50 NF-kB interact physically with STAT3, facilitating NF- $\mathrm{B}$ recruitment to STAT3 promoters and vice versa. In addition, there is another level of regulation, as it has been shown that STAT3 can modify RelA post-translationally by recruitment of the acetyltransferase p300, mediating acetylation of NF$\kappa \mathrm{B}$ and prolongation of its nuclear retention [111]. By that means STAT3-mediated acetylation affects NF- $\mathrm{kB}$ activity a mechanism, which plays a role in cancer - as it is often the result of chronic stimulation with cytokines in a tumor microenvironment. This chronic inflammation results in an elevated constitutive activity of NF- $\mathrm{kB}$ and a release of cytokines such as IL-6, which by itself activates STAT3. This can then further prolong NF- $\mathrm{KB}$ activity via enhancing its acetylation. However, STAT3 can also have a tumor suppressor function as shown recently for intestinal cancer, where it affects the activity of other members of the STAT family and the expression of cell adhesion molecules [112]. While there is in most cases a positive feedback between NF- $\mathrm{BB}$ and STAT3, a mutual inhibition has been reported for NF-kB and p53 [113]. The NF-kB subunit RelA has been shown to inhibit p53 dependent transactivation, while p53 can also suppress NF- $\mathrm{kB}$ transcriptional activity [113]. Recent data indicates that mutant $\mathrm{p} 53$ elevates expression of p52 NF- $\mathrm{kB}$ by inducing acetylation of histones via recruitment of CBP and Stat2 on its promoter via CBP-mediated acetylation [114]. Moreover, it has been shown that the crosstalk between p53 and NF-kB might also be necessary for full activity of NF- $\mathrm{kB}$ after certain types of stimulation even including TNF $\alpha$. This positive cooperativity with NF- $\mathrm{kB}$ seems to be stronger for p53 mutants, providing a potential explanation for the fact that p53 mutants are much more frequently observed in cancer than p53 deletions [115]. More recently, crosstalk of NF-kB with another transcription factor involved in certain types of cancer has been identified - that with the Ets family member ERG.

ERG has a role in various leukemia [116,117] and in Ewing sarcoma [118], and more recently it has been found as being overexpressed in some prostate cancer patients due to a genomic fusion with the androgen dependent promoter of the TMPRSS2 gene [119]. Interestingly, an increased NF- $\mathrm{kB}$ activity was detected particularly in ERG fusion-positive prostate cancer patients and cancer cell lines. It could be shown that the increased NF- $\mathrm{kB}$ activity is associated with phosphorylation of p65 on Ser536 involving signaling through TLR4 [120]. ERG also appears to regulate expression of the NF- $\mathrm{KB}$ target gene ICAM-1 in endothelial cells [121] and additional data suggest that ERG can stimulate the CXR4/CXCL12 axis, which contributes to metastasis [122]. 


\section{Crosstalk of the NF-KB pathway with other signaling pathways}

While our picture of signaling is often rather a onedimensional scheme of a signal cascade it is becoming clear that biological signaling is better described by a dynamic signaling network with complex feedback circuits. However, it is difficult to show this reality of signaling in a printed manner - as the only way to depict that in publications is by drawing connections and arrows between signaling pathways and molecules. There are numerous interactions, links and cooperativities between the NF- $\mathrm{kB}$ pathway and other signaling pathways. One example is the influence of Glycogen Synthase Kinase GSK3- $\beta$ on NF- $\kappa B$ signaling. GSK-3 $\beta$ is a serine/threonine kinase, which was initially identified as a key regulator of insulin dependent glycogen synthesis [123], and is known to be a mediator of a number of major signaling pathways including the phosphatidyl-inositol-3-kinase (PI3K) pathway, the Wnt pathway, Hedgehog signaling and Notch [124]. It could be shown that GSK-3 $\beta$ has a modulating role for the NF- $\mathrm{kB}$ signaling pathway, as it seems to facilitate NF- $\mathrm{KB}$ function through post-transcriptional regulation of the NF- $\mathrm{kB}$ complex [125]. This was later verified as only the overexpression of p65/p50 but not constitutively active IKK2 could rescue pancreatic cancer cells from the effects of GSK-3 $\beta$ inhibition [126]. It was further demonstrated that GSK-3 $\beta$ inhibition or down-regulation leads to a decrease in NF-KB activity within glioma cell lines [127] and that GSK- $3 \beta$ has a role in modulating cell proliferation in prostate and colon cancer $[128,129]$. Interestingly it seems that GSK-3 $\beta$ does not affect the nuclear accumulation of NF$\kappa B$ and can additionally influence NF- $\mathrm{KB}$ activity through epigenetic mechanism as it seems to inhibit the NF- $\mathrm{kB}$ complex from binding to certain target promoters through histone methylation [130]. The exact molecular mechanism of GSK-3 $\beta$ mediated NF- $\mathrm{kB}$ modulation remain, however, elusive and requires further clarification.

Other kinases that have a well-documented link to the NF- $\mathrm{KB}$ pathway are various members of the large mitogen-activated protein kinase family (MAPK) including Jun-N-terminal kinase, JNK, and p38 [131]. Both kinases are also triggered by stimuli that activate NF- $\mathrm{kB}$ (such as $\mathrm{TNF} \alpha$ ), as adapter proteins lead to a branching of the signaling towards different downstream pathways. The mutual influences of these kinases and NF- $\mathrm{kB}$ are pleiotropic. p38 and related kinases are known to be cofactors in NF$\mathrm{KB}$ activation [55], whereas there is a rather counteracting relationship between NF-kB and JNK $[132,133]$. Further members of the kinase family, which activate or regulate NF- $\mathrm{kB}$ include protein kinase C (PKC) $[134,135]$ and Akt triggered by PI3K [136]. However, it is important to note that the effect of a signaling molecule on NF- $\mathrm{KB}$ often strictly depends on the cell type or the micro-environment and that even opposite effects can occur in distinct cell types. This has been reported for instance for the influence of Akt on NF-kB, which is activating in cell types such as epithelial cells, but can be inhibitory in macrophages [137-140].

In addition to adapter molecules, kinases or ubiquitinases and de-ubiquitinases, other classes of molecules were reported to have an influence on NF- $\mathrm{kB}$ activity: These include reactive oxygen species (ROS), which are compounds containing free electrons usually linked to oxygen atoms that are not part of an atomic bond. These compounds react quickly with many other substances leading to their oxidation and they can even react with nitrogen dissolved in the aqueous environment generating so called reactive nitrogen species (RNS), which themselves lead to nitrosylations [141]. ROS are often generated within inflammatory environments by the action of neutrophils, which secrete this reactive class of compounds as a defense mechanism against pathogens by a process called "oxidative burst" [142]. Furthermore, ROS occur as a consequence of mitochondrial dysfunction in the course of ischemia/reperfusion events for instance after myocardial infarcts or in the case of transplanted organs, which have been separated from the blood supply for a while followed by reperfusion and sudden availability of oxygen. ROS can activate NF- $\mathrm{kB}$ by various mechanisms - and on the other hand, they are also regulated by NF- $\mathrm{kB}$. Several target genes of NF- $\mathrm{KB}$ are involved in the de-toxification of ROS but some of them that can also have a pro-oxidant function such as nitric oxid synthases (NOS) pointing at a complex interplay between ROS and NF-кB [143].

\section{Crosstalk between NF-KB and miRNAs}

MicroRNAs (miRNAs) are small noncoding, single stranded RNAs that usually bind to the 3'UTR of protein coding mRNAs typically leading to mRNA cleavage. Alternatively, they can also cause translational repression of their respective targets [144]. Single miRNA-species can have multiple target genes thereby regulating several signaling molecules or pathways. Furthermore, miRNAs are themselves transcriptional targets, thus providing a mechanism for down-regulation of genes by activation of transcription factors. Several miRNAs have been shown to be transcriptional targets of NF-kB including miR-9, miR-21, miR-143, miR-146 and miR-224 [145-150]. These miRNAs are often involved in feedback mechanisms that fine-tune the activity of NF- $\mathrm{KB}$ by targeting some of the upstream signaling molecules or members of the NF- $\mathrm{KB}$ family themselves. Furthermore, NF- $\mathrm{BB}$ can induce the synthesis of proteins that regulate miRNAs. The most important example for that so far is the NF-kB-dependent induction of Lin28, a protein which inhibits the processing and maturation of let-7 miRNAs - a family of miRNAs that is often down-regulated in cancer and which seems to act as tumor suppressor. Let-7 miRNAs target IL-6 - thus a reduction 
of let-7 leads to higher levels of IL-6 and further activation of NF-KB generating a positive feedback loop [151]. In addition to regulating miRNAs directly or indirectly, NF$\kappa B$ activity itself is regulated by several miRNAs that either repress NF- $\mathrm{kB}$ family members directly or some of the upstream signaling molecules.

In a recent report it was shown that miR-15a, miR-16 and miR-223 can influence IKK1 protein expression during macrophage differentiation. Interestingly, these miRNAs did not affect IKK2 or NEMO expression suggesting that they might be modifiers of the non-canonical NF- $\mathrm{kB}$ signaling pathway [152]. Another study showed that miR-502e acts as tumor suppressor by modifying cell proliferation in hepatoma cell lines and hepatocellular carcinoma. The authors suggested that this function is due to the ability of targeting NIK thus directly influencing the non-canonical NF-kB pathway [153]. A depiction of the crosstalk between miRNAs and members of the NF- $\mathrm{kB}$ signaling pathway is summarized very well in [146] (Figure 5).

\section{NF-KB as target in drug combination therapies of cancer}

Given its role in the initiation and progression of cancer, the NF- $\mathrm{kB}$ signaling pathway is a potent node of pharmacological interference in the clinics (see accompanying article). Since NF-кB is also an essential player in the immune response against cancer, there had always been a reluctance to use NF- $\mathrm{kB}$ inhibitors in the treatment of malignancies. Nevertheless, combining classical chemotherapeutics with inhibitors of NF-kB activation seems to result in promising synergies (see [154-165] for some examples). Most cancer drugs are cytotoxic agents that drive proliferating cells into apoptosis, e.g. by interfering with DNA synthesis. Elevated NF- $\mathrm{kB}$ activity in cancer cells provides a survival mechanism by up-regulating anti-apoptotic genes, thereby representing a major causative factor for drug resistance $[155,157,160,164,166]$. Inhibition of NF-KB is also thought to be at least one mechanism of action of proteasome inhibitors in cancer treatment as activation of

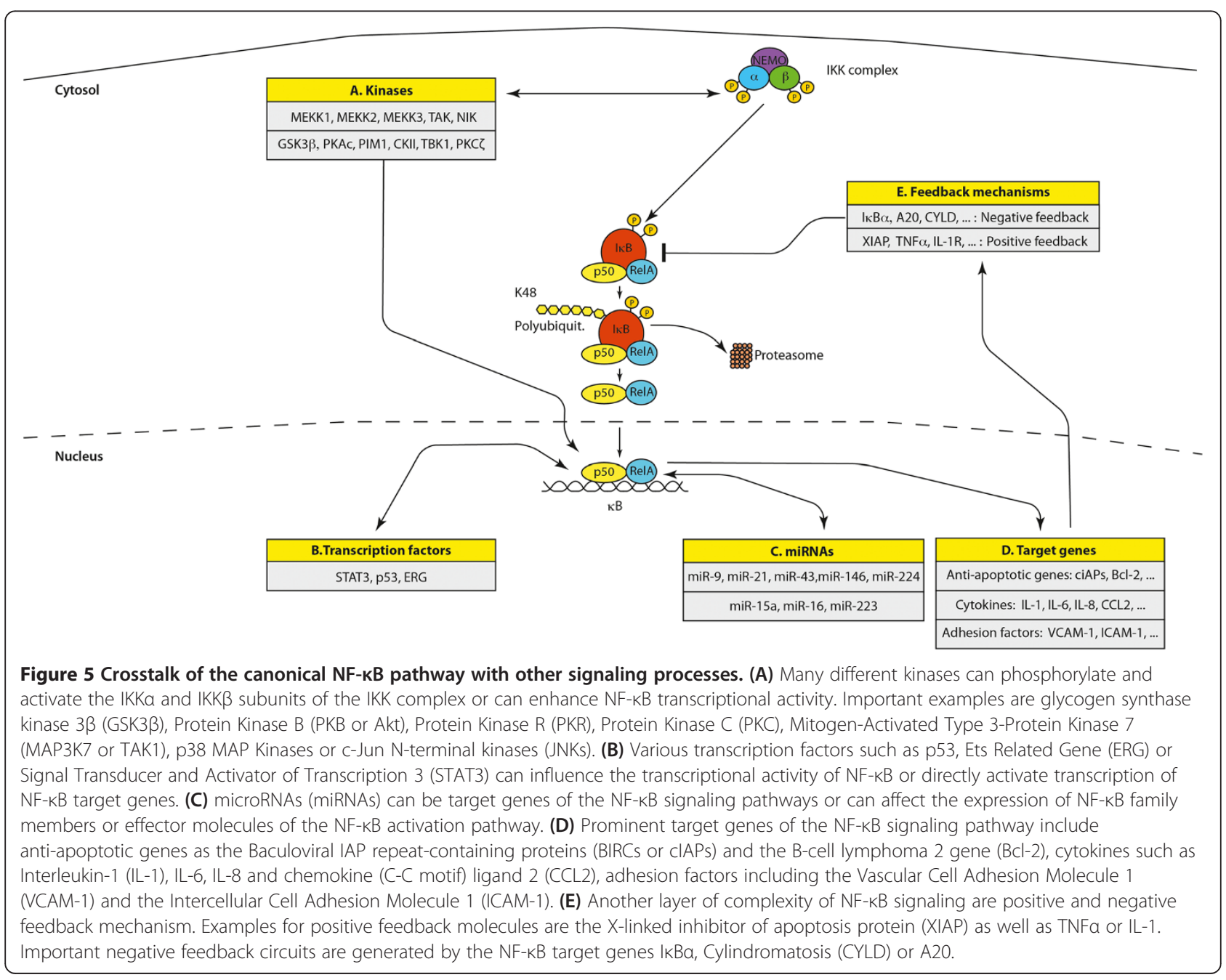


NF- $\kappa B$ requires the proteasomal degradation of I $\kappa B$ molecules $[158,165,167]$.

A crucial aspect in using NF- $\mathrm{KB}$ inhibitors might be an appropriate timing with respect to the cancer stage or the treatment phase. While inhibition of NF-kB is undesirable during the tumor-eliminating phase of the immune system, when immune cells target transformed cells, NF- $\mathrm{kB}$ inhibition is expected to have positive effects in the chronic inflammatory phase of tumor progression. The use of NF- $\mathrm{kB}$ inhibitors might be beneficial for instance, in the treatment of metastatic prostate cancer when applied synchronously with androgen antagonists or drugs that block androgen synthesis. In this case, the withdrawal of androgens induces the apoptosis of many but often not all androgen-dependent prostate cancer cells. The survival of a small fraction of cells - e.g. due to elevated NF- $\mathrm{kB}$ activity and increased anti-apoptosis mechanisms can then result in the development of androgen-independent cancer cells, which are difficult to target. The application of NF$\kappa B$ inhibitors in combination with anti-androgen therapy is expected to result in a more efficient killing of the prostate cancer cells and a slower or less likely recurrence of cancer. Similar considerations apply to the combination of radiotherapy with inhibition of NF- $\mathrm{BB}$, as radiationinduced up-regulation of NF-kB is thought to counteract the therapy by promoting the survival of cancer cells [168]. Another important aspect is that inhibition of NF-KB might target cancer not only directly by blocking anti-apoptosis mechanisms of malignant cells, but also indirectly by shifting macrophages from the tumortolerating M2-polarization stage towards the tumorattacking M1-stage [102].

\section{Conclusion}

NF- $\mathrm{KB}$ represents a central factor in inflammation, stress response, cell differentiation or proliferation as well as cell death. It can be activated by a great variety of stimuli and a complex network of signaling pathways, which can also influence each other. Furthermore, it regulates a huge variety of target genes generating sophisticated feedback circuits that comprise all elements of cellular regulators such as cytokines, growth factors, adhesion molecules, intracellular signaling molecules, transcription factors as well as miRNAs. Thus NF- $\mathrm{kB}$ and members of its signaling network have essential roles in the complete flux of biological information from transcription to regulation of RNAfunction and turnover, the synthesis of proteins, their functions and their degradation.

\section{Abbreviations}

3'UTR: $3^{\prime}$ untranslated region; ANK: Ankyrin; ATF: Activating transcription factor; ATM: Ataxia telangiectasia mutated; BAFFR: B-cell activation factor; $\mathrm{BCL}$ : B-cell lymphoma; BIRC: Baculoviral IAP repeat-containing proteins; CaMKIV: Calmodulin-dependent protein kinase; CBP: CREB-Binding Protein CC: coiled-coil domain; CHK1: Checkpoint kinase 1; CKII: Casein kinase II; CSC: Cancer stem cell; CXCL: Chemokine ligand; CXR: Chemokine receptor;
CYLD: Cylindromatosis; DD: Death domain; DEN: Diethylnitrosamine; DUB: De-ubiquitinase; EGFR: Epidermal growth factor receptor; ERG: Ets Related Gene; GSK: Glycogen synthase kinase; HDAC: Histone deacytlase; HLH: Helix-loop-helix domain; ICAM: Intercellular cell adhesion molecule 1; IKK: IKB kinase; IL: Interleukin; IL-1R: Interleukin-1 receptor; IL-1ß: Interleukin-1

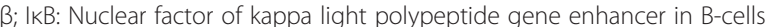
inhibitor; JNK: Jun-N-terminal kinase; LPS: Lipopolysaccharides; LTßR: Lymphtoxin $\beta$-receptor; LZ: Leucin-zipper-like motif; MAPK: Mitogenactivated protein kinase; miRNA: MicroRNA; MMP: Matrix metalloproteinase; MSK1: Mitogen- and stress-activated protein kinase; NBD: NEMO-binding domain; NEMO: NF-KB Essential Modulator; NF-KB: Nuclear factor 'kappa-lightchain-enhancer' of activated B-cells; NIK: NF-kB inducing kinase;

PI3K: Phosphatidyl-inositol-3-kinase; PIM1: Proto-oncogene serine/threonineprotein kinase PIM1; PK: Protein kinase; PKAc: Protein kinase A catalytic subunit; PKCद: Protein kinase Cद; RANK: Receptor activator for nuclear factor kappa B; RHD: Rel homology domain; RNS: Reactive nitrogen species; ROS: Reactive oxygen species; RSK1: Ribosomal s6 kinase; STAT: Signal transducer and activator of transcription; TA: Transactivation domain; TAK: TGF- $\beta$-activating kinase; TAM: Tumor-associated macrophage; TBK1: TANK-binding kinase 1; TLR: Toll-like receptor;

TMPRSS2: Transmembrane protease, serine 2; TNFR: Tumor necrosis factor receptor; TNFa: Tumor necrosis factor a; TNPO1: Transportin 1; TRAF: TNF receptor associated factors; VCAM: Vascular cell adhesion molecule; VEGF: Vascular endothelial growth factor; XIAP: X-linked inhibitor of apoptosis protein; ZF: Zinc-finger domain.

\section{Competing interest}

The authors declare no conflict of interest.

\section{Authors' contribution}

$\mathrm{BH}$ and JS wrote the manuscript. Both authors read and approved the final manuscript.

\section{Authors' information}

$\mathrm{BH}$ is a postdoctoral fellow at the Medical University Vienna, Austria. His research focuses on crosstalk and cooperativity of NF-kB signaling with other signaling pathways with an emphasis on prostate cancer. JS is associate professor at the Medical University Vienna, Austria. His research focuses on aspects of inflammation with a focus on NF-KB signaling and the crosstalk with other signaling pathways.

\section{Acknowledgments}

This work was supported by Austrian Science Fund (FWF), grant P 23690.

Received: 10 May 2013 Accepted: 30 July 2013

Published: 2 August 2013

\section{References}

1. Sen R, Baltimore D: Multiple nuclear factors interact with the immunoglobulin enhancer sequences. Cell 1986, 46:705-716.

2. May MJ, Ghosh S: Signal transduction through NF-kappa B. Immunol Today 1998, 19:80-88.

3. Caamaño J, Hunter CA: NF-kappaB family of transcription factors: central regulators of innate and adaptive immune functions. Clin Microbiol Rev 2002, 15:414-429.

4. May MJ, Ghosh S: Rel/NF-kappa B and I kappa B proteins: an overview. Semin Cancer Biol 1997, 8:63-73.

5. Marienfeld R: RelB forms transcriptionally inactive complexes with RelA/ p65. J Biol Chem 2003, 278:19852-19860.

6. Hayden MSM, Ghosh SS: NF-KB, the first quarter-century: remarkable progress and outstanding questions. Genes Dev 2012, 26:203-234.

7. Bours V, Franzoso G, Azarenko V, Park S, Kanno T, Brown K, Siebenlist U: The oncoprotein $\mathrm{Bcl}-3$ directly transactivates through kappa $\mathrm{B}$ motifs via association with DNA-binding p50B homodimers. Cell 1993, 72:729-739.

8. Franzoso G, Bours V, Azarenko V, Park S, Tomita-Yamaguchi M, Kanno T, Brown K, Siebenlist U: The oncoprotein Bcl-3 can facilitate NF-kappa B-mediated transactivation by removing inhibiting p50 homodimers from select kappa B sites. EMBO J 1993, 12:3893-3901.

9. Nolan GP, Fujita T, Bhatia K, Huppi C, Liou HC, Scott ML, Baltimore D: The bcl-3 proto-oncogene encodes a nuclear I kappa B-like molecule that 
preferentially interacts with NF-kappa B p50 and p52 in a phosphorylation-dependent manner. Mol Cell Biol 1993, 13:3557-3566.

10. Wong D, Teixeira A, Oikonomopoulos S, Humburg P, Lone IN, Saliba D, Siggers T, Bulyk M, Angelov D, Dimitrov S, Udalova IA, Ragoussis J: Extensive characterization of NF-KB binding uncovers non-canonical motifs and advances the interpretation of genetic functional traits. Genome Biol 2011, 12:R70.

11. Oeckinghaus A, Ghosh S: The NF- B family of transcription factors and its regulation. Cold Spring Harb Perspect Biol 2009, 1:a000034-a000034.

12. Birbach A, Gold P, Binder BR, Hofer E, De Martin R, Schmid JA: Signaling molecules of the NF-kappa B pathway shuttle constitutively between cytoplasm and nucleus. J Biol Chem 2002, 277:10842-10851.

13. Huang TT, Kudo N, Yoshida M, Miyamoto S: A nuclear export signal in the $\mathrm{N}$-terminal regulatory domain of IkappaBalpha controls cytoplasmic localization of inactive NF-kappaB/lkappaBalpha complexes. Proc Natl Acad Sci USA 2000, 97:1014-1019.

14. Hayden MS, Ghosh S: Shared principles in NF-kappaB signaling. Cell 2008, 132:344-362.

15. Tan P, Fuchs SY, Chen A, Wu K, Gomez C, Ronai Z, Pan ZQ: Recruitment of a ROC1-CUL1 ubiquitin ligase by Skp1 and HOS to catalyze the ubiquitination of I kappa B alpha. Mol Cell 1999, 3:527-533.

16. Wu K, Fuchs SY, Chen A, Tan P, Gomez C, Ronai Z, Pan ZQ: The SCF(HOS/ beta-TRCP)-ROC1 E3 ubiquitin ligase utilizes two distinct domains within CUL1 for substrate targeting and ubiquitin ligation. Mol Cell Biol 2000, 20:1382-1393

17. Delhase M, Hayakawa M, Chen Y, Karin M: Positive and negative regulation of IkappaB kinase activity through IKKbeta subunit phosphorylation. Science 1999, 284:309-313.

18. Schmid JA, Birbach A: IkappaB kinase beta (IKKbeta/IKK2/IKBKB)-a key molecule in signaling to the transcription factor NF-kappaB. Cytokine Growth Factor Rev 2008, 19:157-165.

19. Ling L, Cao Z, Goeddel DV: NF-kappaB-inducing kinase activates IKK-alpha by phosphorylation of Ser-176. Proc Natl Acad Sci USA 1998, 95:3792-3797.

20. Malinin NL, Boldin MP, Kovalenko AV, Wallach D: MAP3K-related kinase involved in NF-kappaB induction by TNF, CD95 and IL-1. Nature 1997, 385:540-544.

21. Nakano H, Shindo M, Sakon S, Nishinaka S, Mihara M, Yagita H, Okumura K: Differential regulation of IkappaB kinase alpha and beta by two upstream kinases, NF-kappaB-inducing kinase and mitogen-activated protein kinase/ERK kinase kinase-1. Proc Natl Acad Sci USA 1998, 95:3537-3542.

22. Zhao Q: Mitogen-activated protein Kinase/ERK Kinase Kinases 2 and 3 activate nuclear factor-kappa B through Ikappa B Kinase-alpha and Ikappa B Kinase-beta. J Biol Chem 1999, 274:8355-8358.

23. Ninomiya-Tsuji J, Kishimoto K, Hiyama A, Inoue J, Cao Z, Matsumoto K: The kinase TAK1 can activate the NIK-I kappaB as well as the MAP kinase cascade in the IL-1 signalling pathway. Nature 1999, 398:252-256.

24. Wang C, Deng L, Hong M, Akkaraju GR, Inoue J, Chen ZJ: TAK1 is a ubiquitin-dependent kinase of MKK and IKK. Nature 2001, 412:346-351.

25. Huang Q, Yang J, Lin Y, Walker C, Cheng J, Liu Z-G, Su B: Differential regulation of interleukin 1 receptor and Toll-like receptor signaling by MEKK3. Nat Immunol 2003, 5:98-103.

26. Qin J: TLR8-mediated NF- B and JNK Activation Are TAK1-independent and MEKK3-dependent. J Biol Chem 2006, 281:21013-21021.

27. Deng L, Wang C, Spencer E, Yang L, Braun A, You J, Slaughter C, Pickart C, Chen ZJ: Activation of the IkappaB kinase complex by TRAF6 requires a dimeric ubiquitin-conjugating enzyme complex and a unique polyubiquitin chain. Cell 2000, 103:351-361.

28. Habelhah H, Takahashi S, Cho S-G, Kadoya T, Watanabe T, Ronai Z: Ubiquitination and translocation of TRAF2 is required for activation of JNK but not of p38 or NF-kappaB. EMBO J 2004, 23:322-332.

29. Iwai K, Tokunaga F: Linear polyubiquitination: a new regulator of NF-KB activation. EMBO Rep 2009, 10:706-713.

30. Tokunaga F, Sakata S-I, Saeki Y, Satomi Y, Kirisako T, Kamei K, Nakagawa T, Kato M, Murata S, Yamaoka S, Yamamoto M, Akira S, Takao T, Tanaka K, Iwai $\mathrm{K}$ : Involvement of linear polyubiquitylation of NEMO in NF-KB activation. Nat Cell Biol 2009, 11:123-132.

31. Wertz IE, O'Rourke KM, Zhou H, Eby M, Aravind L, Seshagiri S, Wu P, Wiesmann C, Baker R, Boone DL, Ma A, Koonin EV, Dixit VM: Deubiquitination and ubiquitin ligase domains of $\mathrm{A} 20$ downregulate NF-kappaB signalling. Nature 2004, 430:694-699.
32. Trompouki E, Hatzivassiliou E, Tsichritzis T, Farmer H, Ashworth A, Mosialos G: CYLD is a deubiquitinating enzyme that negatively regulates NF-kappaB activation by TNFR family members. Nature 2003, 424:793-796.

33. Perkins ND, Gilmore TD: Good cop, bad cop: the different faces of NF-kappaB. Cell Death Differ 2006, 13:759-772.

34. Perkins ND: Integrating cell-signalling pathways with NF-kappaB and IKK function. Nat Rev Mol Cell Biol 2007, 8:49-62.

35. Sun S-C: Non-canonical NF-KB signaling pathway. Cell Res 2010, 21:71-85.

36. Xiao G, Harhaj EW, Sun SC: NF-kappaB-inducing kinase regulates the processing of NF-kappaB2 p100. Mol Cell 2001, 7:401-409.

37. Dejardin E, Droin NM, Delhase M, Haas E, Cao Y, Makris C, Li Z-W, Karin M Ware CF, Green DR: The lymphotoxin-beta receptor induces different patterns of gene expression via two NF-kappaB pathways. Immunity 2002, 17:525-535.

38. Solan NJ, Miyoshi H, Carmona EM, Bren GD, Paya CV: RelB cellular regulation and transcriptional activity are regulated by p100. J Biol Chem 2002, 277:1405-1418.

39. Senftleben U, Cao Y, Xiao G, Greten FR, Krähn G, Bonizzi G, Chen Y, Hu Y, Fong A, Sun SC, Karin M: Activation by IKKalpha of a second, evolutionary conserved, NF-kappa B signaling pathway. Science 2001, 293:1495-1499.

40. Huang TT, Wuerzberger-Davis SM, Wu Z-H, Miyamoto S: Sequential modification of NEMO/IKKgamma by SUMO-1 and ubiquitin mediates NF-kappaB activation by genotoxic stress. Cell 2003, 115:565-576.

41. Kato T, Delhase M, Hoffmann A, Karin M: CK2 Is a C-terminal IkappaB Kinase responsible for NF-kappaB activation during the UV response. Mol Cell 2003, 12:829-839.

42. Takada Y, Mukhopadhyay A, Kundu GC, Mahabeleshwar GH, Singh S, Aggarwal BB: Hydrogen peroxide activates NF-kappa B through tyrosine phosphorylation of I kappa B alpha and serine phosphorylation of p65: evidence for the involvement of I kappa $B$ alpha kinase and Syk protein-tyrosine kinase. J Biol Chem 2003, 278:24233-24241.

43. Habib AA: The epidermal growth factor receptor engages receptor interacting protein and nuclear factor-kappa B (NF-kappa B)-inducing kinase to activate NF-kappa B. Identification of a novel receptor-tyrosine kinase signalosome. J Biol Chem 2000, 276:8865-8874.

44. Alberti C, Pinciroli P, Valeri B, Ferri R, Ditto A, Umezawa K, Sensi M, Canevari $\mathrm{S}$, Tomassetti A: Ligand-dependent EGFR activation induces the co-expression of IL-6 and PAI-1 via the NFkB pathway in advanced-stage epithelial ovarian cancer. Oncogene 2011, 31:4139-4149.

45. Tieri P, Termanini A, Bellavista E, Salvioli S, Capri M, Franceschi C: Charting the NF-KB pathway interactome map. PLoS ONE 2012, 7:e32678.

46. Latimer M, Ernst MK, Dunn LL, Drutskaya M, Rice NR: The N-terminal domain of IkappaB alpha masks the nuclear localization signal(s) of p50 and c-Rel homodimers. Mol Cell Biol 1998, 18:2640-2649.

47. Bouwmeester T, Bauch A, Ruffner H, Angrand P-O, Bergamini G, Croughton K, Cruciat C, Eberhard D, Gagneur J, Ghidelli S, Hopf C, Huhse B, Mangano R, Michon A-M, Schirle M, Schlegl J, Schwab M, Stein MA, Bauer A, Casari G, Drewes G, Gavin A-C, Jackson DB, Joberty G, Neubauer G, Rick J, Kuster B, Superti-Furga G: A physical and functional map of the human TNF-a/NF-KB signal transduction pathway. Nat Cell Biol 2004, 6:97-105.

48. Scheinman Rl, Beg AA, Baldwin AS: NF-kappa B p100 (Lyt-10) is a component of H2TF1 and can function as an I kappa B-like molecule. Mol Cell Biol 1993, 13:6089-6101.

49. Barré B, Perkins ND: A cell cycle regulatory network controlling NF-KB subunit activity and function. EMBO J 2007, 26:4841-4855.

50. Ashburner BP, Westerheide SD, Baldwin AS: The p65 (RelA) subunit of NF- B interacts with the histone deacetylase (HDAC) corepressors HDAC1 and HDAC2 to negatively regulate gene expression. Mol Cell Biol 2001, 21:7065-7077.

51. Gerritsen ME, Williams AJ, Neish AS, Moore S, Shi Y, Collins T: CREB-binding protein/p300 are transcriptional coactivators of p65. Proc Natl Acad SC USA 1997, 94:2927-2932.

52. Chapman NR, Webster GA, Gillespie PJ, Wilson BJ, Crouch DH, Perkins ND: A novel form of the RelA nuclear factor kappaB subunit is induced by and forms a complex with the proto-oncogene c-Myc. Biochem J 2002, 366:459-469.

53. Frank AK, Leu JI-J, Zhou Y, Devarajan K, Nedelko T, Klein-Szanto A, Hollstein M, Murphy ME: The codon 72 polymorphism of p53 regulates interaction with NF-\{kappa\}B and transactivation of genes involved in immunity and inflammation. Mol Cell Biol 2011, 31:1201-1213. 
54. Anrather J, Racchumi G, ladecola C: cis-acting, element-specific transcriptional activity of differentially phosphorylated nuclear factorkappa B. Journal of Biological Chemistry 2004, 280:244-252.

55. Vermeulen L, De Wilde G, Van Damme P, Vanden Berghe W, Haegeman G: Transcriptional activation of the NF-kappaB p65 subunit by mitogenand stress-activated protein kinase-1 (MSK1). EMBO J 2003, 22:1313-1324.

56. Nihira K, Ando Y, Yamaguchi T, Kagami Y, Miki Y, Yoshida K: Pim-1 controls NF. Cell Death and Differentiation 2009, 17:689-698.

57. Zhong $H$, SuYang $H$, Erdjument-Bromage $H$, Tempst $P$, Ghosh S: The transcriptional activity of NF-kappaB is regulated by the lkappaBassociated PKAc subunit through a cyclic AMP-independent mechanism. Cell 1997, 89:413-424.

58. Jamaluddin M, Wang S, Boldogh I, Tian B, Brasier AR: TNF-a-induced NF-kB/RelA Ser276 phosphorylation and enhanceosome formation is mediated by an ROS-dependent PKAc pathway. Cell Signal 2007, 19:1419-1433.

59. Duran A, Diaz-Meco MT, Moscat J: Essential role of RelA Ser311 phosphorylation by zetaPKC in NF-kappaB transcriptional activation. EMBO J 2003, 22:3910-3918.

60. Schwabe RF, Brenner DA: Role of glycogen synthase kinase-3 in TNFalpha-induced NF-kappaB activation and apoptosis in hepatocytes. Am J Physiol Gastrointest Liver Physiol 2002, 283:G204-G211.

61. Yang F, Tang E, Guan K, Wang C-Y: IKK beta plays an essential role in the phosphorylation of RelA/p65 on serine 536 induced by lipopolysaccharide. J Immunol 2003, 170:5630-5635.

62. Schwabe RF: IKK phosphorylates p65 at $\$ 468$ in transactivaton domain 2. The: FASEB Journal; 2005.

63. Buss $\mathrm{H}$ : Constitutive and interleukin-1-inducible phosphorylation of p65 NF- B at serine 536 is mediated by multiple protein kinases including I B kinase (IKK)-, IKK, IKK, TRAF family member-associated (TANK)-binding kinase 1 (TBK1), and an unknown kinase and couples p65 to TATAbinding protein-associated factor II31-mediated interleukin-8 transcription. Journal of Biological Chemistry 2004, 279:55633-55643.

64. Mattioli I, Geng H, Sebald A, Hodel M, Bucher C, Kracht M, Schmitz ML: Inducible Phosphorylation of NF- B p65 at Serine 468 by T Cell Costimulation Is Mediated by IKK. Journal of Biological Chemistry 2006, 281:6175-6183.

65. Wang D: Tumor necrosis factor alpha -induced phosphorylation of RelA/ p65 on Ser529 is controlled by casein kinase II. Journal of Biological Chemistry 2000, 275:32592-32597.

66. Soon Bae J, Kyoo Jang M, Hong S, An WG, Choi YH, Kim HD, Cheong J: Phosphorylation of NF-KB by calmodulin-dependent kinase IV activates anti-apoptotic gene expression. Biochem Biophys Res Commun 2003, 305:1094-1098.

67. Delhase M, Kim SY, Lee H, Naiki-Ito A, Chen Y, Ahn ER, Murata K, Kim SJ, Lautsch N, Kobayashi KS, Shirai T, Karin M, Nakanishi M: PNAS Plus: TANKbinding kinase 1 (TBK1) controls cell survival through PAI-2/serpinB2 and transglutaminase 2. Proceedings of the National Academy of Sciences 2012, 109:E177-E186.

68. Lawrence T, Bebien M, Liu GY, Nizet V, Karin M: IKKalpha limits macrophage NF-kappaB activation and contributes to the resolution of inflammation. Nature 2005, 434:1138-1143.

69. Bohuslav J: p53 Induces NF- B activation by an I B kinase-independent mechanism involving phosphorylation of p65 by ribosomal S6 kinase 1. Journal of Biological Chemistry 2004, 279:26115-26125.

70. Sabatel H, Di Valentin E, Gloire G, Dequiedt F, Piette J, Habraken Y. Phosphorylation of p65(RelA) on Ser547 by ATM represses NF-kB -dependent transcription of specific genes after genotoxic stress. PLOS ONE 2012, 7:e38246.

71. Ryo A, Suizu F, Yoshida Y, Perrem K, Liou Y-C, Wulf G, Rottapel R, Yamaoka S, Lu KP: Regulation of NF-kappaB signaling by Pin1-dependent prolyl isomerization and ubiquitin-mediated proteolysis of p65/RelA. Molecular Cell 2003, 12:1413-1426.

72. Yeh PY: Suppression of MEK/ERK signaling pathway enhances cisplatininduced NF- B activation by protein phosphatase 4-mediated NF- B p65 Thr dephosphorylation. Journal of Biological Chemistry 2004, 279:26143-26148

73. Rocha S, Garrett MD, Campbell KJ, Schumm K, Perkins ND: Regulation of NF-kappaB and p53 through activation of ATR and Chk1 by the ARF tumour suppressor. EMBO J 2005, 24:1157-1169.

74. Pahl HL: Activators and target genes of Rel/NF-kappaB transcription factors. Oncogene 1999, 18:6853-6866.
75. Klement JF, Rice NR, Car BD, Abbondanzo SJ, Powers GD, Bhatt PH, Chen $\mathrm{CH}$, Rosen CA, Stewart CL: IkappaBalpha deficiency results in a sustained NF-kappaB response and severe widespread dermatitis in mice. Mol Cell Biol 1996, 16:2341-2349.

76. Ben-Neriah Y, Karin M: Inflammation meets cancer, with NF-KB as the matchmaker. Nat Immunol 2011, 12:715-723.

77. Disis ML: Immune regulation of cancer. J Clin Oncol 2010, 28:4531-4538.

78. Smyth MJ, Dunn GP, Schreiber RD: Cancer immunosurveillance and immunoediting: the roles of immunity in suppressing tumor development and shaping tumor immunogenicity. Adv Immunol 2006, 90:1-50.

79. Dunn GP, Old $L$, Schreiber RD: The three Es of cancer immunoediting. Annu Rev Immunol 2004, 22:329-360.

80. Guttridge DC, Albanese C, Reuther JY, Pestell RG, Baldwin AS: NF-kappaB controls cell growth and differentiation through transcriptional regulation of cyclin D1. Mol Cell Biol 1999, 19:5785-5799.

81. La Rosa FA, Pierce JW, Sonenshein GE: Differential regulation of the c-myc oncogene promoter by the NF-kappa B rel family of transcription factors. Mol Cell Biol 1994, 14:1039-1044.

82. Perkins ND: Achieving transcriptional specificity with NF-kappa B. The international journal of biochemistry \& cell biology 1997, 29:1433-1448.

83. Liou G-Y, Storz P: Reactive oxygen species in cancer. Free Radic Res 2010, 44:479-496.

84. Huber MA, Azoitei N, Baumann B, Grünert S, Sommer A, Pehamberger $H$, Kraut N, Beug H, Wirth T: NF-KB is essential for epithelial-mesenchymal transition and metastasis in a model of breast cancer progression. $J$ Clin Investig 2004, 114:569-581.

85. Xie T-X, Xia Z, Zhang N, Gong W, Huang S: Constitutive NF-kappaB activity regulates the expression of VEGF and IL-8 and tumor angiogenesis of human glioblastoma. Oncol Rep 2010, 23:725-732.

86. Yoshida A, Yoshida S, Ishibashi T, Kuwano M, Inomata H: Suppression of retinal neovascularization by the NF-kappaB inhibitor pyrrolidine dithiocarbamate in mice. Invest Ophthalmol Vis Sci 1999, 40:1624-1629.

87. Mantovani A, Allavena P, Sica A, Balkwill F: Cancer-related inflammation. Nature 2008, 454:436-444.

88. Courtois G, Gilmore TD: Mutations in the NF-kB signaling pathway: implications for human disease. Oncogene 2006, 25:6831-6843.

89. Neri A, Chang CC, Lombardi L, Salina M, Corradini P, Maiolo AT, Chaganti RS, Dalla-Favera R: B cell lymphoma-associated chromosomal translocation involves candidate oncogene lyt-10, homologous to NF-kappa B p50. Cell 1991, 67:1075-1087.

90. Fracchiolla NS, Lombardi L, Salina M, Migliazza A, Baldini L, Berti E, Cro L, Polli E, Maiolo AT, Neri A: Structural alterations of the NF-kappa B transcription factor lyt-10 in lymphoid malignancies. Oncogene 1993, 8:2839-2845.

91. Rayet B, Gélinas C: Aberrant rel/nfkb genes and activity in human cancer. Oncogene 1999, 18:6938-6947.

92. Rao PH, Houldsworth J, Dyomina K, Parsa NZ, Cigudosa JC, Louie DC, Popplewell L, Offit K, Jhanwar SC, Chaganti RS: Chromosomal and gene amplification in diffuse large B-cell lymphoma. Blood 1998, 92:234-240.

93. Ohno H, Takimoto G, McKeithan TW: The candidate proto-oncogene bcl-3 is related to genes implicated in cell lineage determination and cell cycle control. Cell 1990, 60:991-997.

94. Barth TF, Döhner H, Werner CA, Stilgenbauer S, Schlotter M, Pawlita M, Lichter $\mathrm{P}$, Möller $\mathrm{P}$, Bentz M: Characteristic pattern of chromosomal gains and losses in primary large B-cell lymphomas of the gastrointestinal tract. Blood 1998, 91:4321-4330.

95. DiDonato JA, Mercurio F, Karin M: NF-kB and the link between inflammation and cancer. Immunol Rev 2012, 246:379-400

96. Pflueger D, Terry S, Sboner A, Habegger L, Esgueva R, Lin P-C, Svensson MA, Kitabayashi N, Moss BJ, MacDonald TY, Cao X, Barrette T, Tewari AK, Chee MS, Chinnaiyan AM, Rickman DS, Demichelis F, Gerstein MB, Rubin MA Discovery of non-ETS gene fusions in human prostate cancer using next-generation RNA sequencing. Genome Res 2011, 21:56-67.

97. Jiao X, Wood LD, Lindman M, Jones S, Buckhaults P, Polyak K, Sukumar S, Carter H, Kim D, Karchin R, Sjöblom T: Somatic mutations in the Notch, NF-KB, PIK3CA, and Hedgehog pathways in human breast cancers. Genes Chromosomes Cancer 2012, 51:480-489.

98. Greten FR, Eckmann L, Greten TF, Park JM, Li Z-W, Egan LJ, Kagnoff MF, Karin M: IKKbeta links inflammation and tumorigenesis in a mouse model of colitis-associated cancer. Cell 2004, 118:285-296. 
99. Karin M: NF- B as a critical link between inflammation and cancer. Cold Spring Harb Perspect Biol 2009, 1:a000141-a000141.

100. Yang J, Splittgerber R, Yull FE, Kantrow S, Ayers GD, Karin M, Richmond A: Conditional ablation of Ikkb inhibits melanoma tumor development in mice. J Clin Invest 2010, 120:2563-2574.

101. Takahashi H, Ogata H, Nishigaki R, Broide DH, Karin M: Tobacco smoke promotes lung tumorigenesis by triggering IKKbeta- and JNK1dependent inflammation. Cancer Cell 2010, 17:89-97.

102. Hagemann T, Lawrence T, McNeish I, Charles KA, Kulbe H, Thompson RG, Robinson SC, Balkwill FR: "Re-educating" tumor-associated macrophages by targeting NF-kappaB. J Exp Med 2008, 205:1261-1268.

103. Balkwill F, Mantovani A: Inflammation and cancer: back to Virchow? Lancet 2001, 357:539-545.

104. Chefetz I, Holmberg JC, Alvero AB, Visintin I, Mor G: Inhibition of Aurora-A kinase induces cell cycle arrest in epithelial ovarian cancer stem cells by affecting NFkB pathway. Cell Cycle 2011, 10:2206-2214.

105. Alvero AB, Chen R, Fu H-H, Montagna M, Schwartz PE, Rutherford T, Silasi DA, Steffensen KD, Waldstrom M, Visintin I, Mor G: Molecular phenotyping of human ovarian cancer stem cells unravels the mechanisms for repair and chemoresistance. Cell Cycle 2009, 8:158-166.

106. Böhlig $L$, Rother $K$ : One function-multiple mechanisms: the manifold activities of p53 as a transcriptional repressor. J Biomed Biotechnol 2011, 2011:1-15.

107. Grivennikov SI, Karin M: Dangerous liaisons: STAT3 and NF-kappaB collaboration and crosstalk in cancer. Cytokine Growth Factor Rev 2010, 21:11-19.

108. Perkins ND: The diverse and complex roles of NF-KB subunits in cancer. Nat Rev Cancer 2012, 12:121-132.

109. Yang J, Liao X, Agarwal MK, Barnes L, Auron PE, Stark GR: Unphosphorylated STAT3 accumulates in response to IL-6 and activates transcription by binding to NF B. Genes Dev 2007, 21:1396-1408.

110. Dauer DJ, Ferraro B, Song L, Yu B, Mora L, Buettner R, Enkemann S, Jove R, Haura EB: Stat3 regulates genes common to both wound healing and cancer. Oncogene 2005, 24:3397-3408.

111. Lee H, Herrmann A, Deng J-H, Kujawski M, Niu G, Li Z, Forman S, Jove R, Pardoll DM, Yu H: Persistently activated Stat3 maintains constitutive NF-kappaB activity in tumors. Cancer Cell 2009, 15:283-293.

112. Musteanu M, Blaas L, Mair M, Schlederer M, Bilban M, Tauber S, Esterbauer H, Mueller M, Casanova E, Kenner L, Poli V, Eferl R: Stat3 Is a negative regulator of intestinal tumor progression in ApcMin mice. YGAST 2010, 138(e5):1003-1011.

113. Webster GA, Perkins ND: Transcriptional Cross Talk between NF-KB and p53. Mol Cell Biol 1999, 19(5):3485.

114. Vaughan CA, Singh S, Windle B, Sankala HM, Graves PR, Andrew Yeudall W Deb SP, Deb S: p53 mutants induce transcription of NF-kB2 in H1299 cells through CBP and STAT binding on the NF-KB2 promoter and gain of function activity. Arch Biochem Biophys 2012, 518:79-88.

115. Schneider G, Henrich A, Greiner G, Wolf V, Lovas A, Wieczorek M, Wagner $T$, Reichardt S, Werder Von A, Schmid RM, Weih F, Heinzel T, Saur D, Kramer $\mathrm{OH}$ : Cross talk between stimulated NF-kappaB and the tumor suppressor p53. Oncogene 2010, 29:2795-2806.

116. Ichikawa H, Shimizu K, Hayashi Y, Ohki M: An RNA-binding protein gene, TLS/FUS, is fused to ERG in human myeloid leukemia with $t(16 ; 21)$ chromosomal translocation. Cancer Res 1994, 54:2865-2868.

117. Prasad DD, Ouchida M, Lee L, Rao VN, Reddy ES: TLS/FUS fusion domain of TLS/FUS-erg chimeric protein resulting from the $t(16 ; 21)$ chromosomal translocation in human myeloid leukemia functions as a transcriptional activation domain. Oncogene 1994, 9:3717-3729.

118. Sorensen PH, Lessnick SL, Lopez-Terrada D, Liu X-F, Triche TJ, Denny CT: A second Ewing's sarcoma translocation, $t(21 ; 22)$, fuses the EWS gene to another ETS-family transcription factor, ERG. Nat Genet 1994, 6:146-151.

119. Tomlins SA: Recurrent fusion of TMPRSS2 and ETS transcription factor genes in prostate cancer. Science 2005, 310:644-648.

120. Wang J, Cai Y, Shao LJ, Siddiqui J, Palanisamy N, Li R, Ren C, Ayala G, Ittmann M: Activation of NF- B by TMPRSS2/ERG fusion isoforms through toll-like receptor-4. Cancer Res 2011, 71:1325-1333.

121. Dryden NHN, Sperone AA, Martin-Almedina SS, Hannah RLR, Birdsey GMG, Khan STS, Layhadi JAJ, Mason JCJ, Haskard DOD, Göttgens BB, Randi AMA: The transcription factor Erg controls endothelial cell quiescence by repressing activity of nuclear factor (NF)-kB p65. J Biol Chem 2012, 287:12331-12342
122. Juan Cai PKRSAKSSMLCSRC: Androgens induce functional CXCR4 through ERG factor expression in TMPRSS2-ERG fusion-positive prostate cancer cells. Translational Oncology 2010, 3:195

123. Rylatt DB, Aitken A, Bilham T, Condon GD, Embi N, Cohen P: Glycogen synthase from rabbit skeletal muscle. Amino acid sequence at the sites phosphorylated by glycogen synthase kinase-3, and extension of the $\mathrm{N}$-terminal sequence containing the site phosphorylated by phosphorylase kinase. Eur J Biochem 1980, 107:529-537.

124. Kaidanovich-Beilin O, Woodgett JR: GSK-3: Functional Insights from Cell Biology and Animal Models. Front Mol Neurosci 2011, 4:40.

125. Hoeflich KP, Luo J, Rubie EA, Tsao MS, Jin O, Woodgett JR: Requirement for glycogen synthase kinase-3beta in cell survival and NF-kappaB activation. Nature 2000, 406:86-90.

126. Ougolkov AV, Fernandez-Zapico ME, Savoy DN, Urrutia RA, Billadeau DD: Glycogen synthase kinase-3beta participates in nuclear factor kappaBmediated gene transcription and cell survival in pancreatic cancer cells. Cancer Res 2005, 65:2076-2081.

127. Kotliarova S, Pastorino S, Kovell LC, Kotliarov Y, Song H, Zhang W, Bailey R, Maric D, Zenklusen JC, Lee J, Fine HA: Glycogen synthase kinase-3 inhibition induces glioma cell death through c-MYC, nuclear factorkappaB, and glucose regulation. Cancer Res 2008, 68:6643-6651.

128. Mazor M, Kawano Y, Zhu H, Waxman J, Kypta RM: Inhibition of glycogen synthase kinase-3 represses androgen receptor activity and prostate cancer cell growth. Oncogene 2004, 23:7882-7892.

129. Shakoori A, Ougolkov A, Yu ZW, Zhang B, Modarressi MH, Billadeau DD, Mai M, Takahashi Y, Minamoto T: Deregulated GSK3beta activity in colorectal cancer: its association with tumor cell survival and proliferation. Biochem Biophys Res Commun 2005, 334:1365-1373.

130. Ougolkov AV, Bone ND, Fernandez-Zapico ME, Kay NE, Billadeau DD: Inhibition of glycogen synthase kinase-3 activity leads to epigenetic silencing of nuclear factor kappaB target genes and induction of apoptosis in chronic lymphocytic leukemia B cells. Blood 2007, 110:735-742.

131. Schulze-Osthoff K, Ferrari D, Riehemann K, Wesselborg S: Regulation of NF-KB activation by MAP kinase cascades. Immunobiology 1997, 198:35-49.

132. De Smaele E, Zazzeroni F, Papa S, Nguyen DU, Jin R, Jones J, Cong R, Franzoso G: Induction of gadd45beta by NF-kappaB downregulates pro-apoptotic JNK signalling. Nature 2001, 414:308-313.

133. Papa S, Zazzeroni F, Bubici C, Jayawardena S, Alvarez K, Matsuda S, Nguyen DU, Pham CG, Nelsbach AH, Melis T, De Smaele E, Tang W-J, D'Adamio L, Franzoso G: Gadd45 beta mediates the NF-kappa B suppression of JNK signalling by targeting MKK7/JNKK2. Nat Cell Biol 2004, 6:146-153.

134. Moscat J, Diaz-Meco MT, Rennert P: NF-kappaB activation by protein kinase $C$ isoforms and B-cell function. EMBO Rep 2003, 4:31-36.

135. Lin X, O'Mahony A, Mu Y, Geleziunas R, Greene WC: Protein kinase C-theta participates in NF-kappa B activation induced by CD3-CD28 costimulation through selective activation of ikappa B kinase beta. Mol Cell Biol 2000, 20:2933-2940.

136. Dan HC, Cooper MJ, Cogswell PC, Duncan JA, Ting JP-Y, Baldwin AS: Aktdependent regulation of NF-\{kappa\}B is controlled by mTOR and Raptor in association with IKK. Genes \& Development 2008, 22:1490-1500.

137. Park YC, Lee CH, Kang HS, Chung HT, Kim HD: Wortmannin, a specific inhibitor of phosphatidylinositol-3-kinase, enhances LPS-induced NO production from murine peritoneal macrophages. Biochem Biophys Res Commun 1997, 240:692-696.

138. Guha M: The phosphatidylinositol 3-kinase-Akt pathway limits lipopolysaccharide activation of signaling pathways and expression of inflammatory mediators in human monocytic cells. Journal of Biological Chemistry 2002, 277:32124-32132.

139. Zhao L, Lee JY, Hwang DH: The phosphatidylinositol 3-kinase/Akt pathway negatively regulates Nod2-mediated NF-KB pathway. Biochem Pharmacol 2008, 75:1515-1525.

140. Arbibe L, Mira JP, Teusch N, Kline L, Guha M, Mackman N, Godowski PJ, Ulevitch RJ, Knaus UG: Toll-like receptor 2-mediated NF-kappa B activation requires a Rac1-dependent pathway. Nat Immunol 2000, 1:533-540.

141. Trachootham D, Lu W, Ogasawara MA, Valle NR-D, Huang P: Redox regulation of cell survival. Antioxid Redox Signal 2008, 10:1343-1374.

142. Bhakdi S, Martin E: Superoxide generation by human neutrophils induced by low doses of Escherichia coli hemolysin. Infect Immun 1991, 59:2955-2962 
143. Morgan MJ, Liu Z-G: Crosstalk of reactive oxygen species and NF-KB signaling. Cell Res 2010, 21:103-115.

144. Bartel DP: MicroRNAs: genomics, biogenesis, mechanism, and function. Cell 2004, 116:281-297.

145. Bazzoni F, Rossato M, Fabbri M, Gaudiosi D, Mirolo M, Mori L, Tamassia N, Mantovani A, Cassatella MA, Locati M: Induction and regulatory function of miR-9 in human monocytes and neutrophils exposed to proinflammatory signals. Proc Natl Acad Sci USA 2009, 106:5282-5287.

146. Ma X, Becker Buscaglia LE, Barker JR, Li Y: MicroRNAs in NF- B signaling. Journal of Molecular Cell Biology 2011, 3:159-166

147. Niu J, Shi Y, Tan G, Yang CH, Fan M, Pfeffer LM, Wu Z-H: DNA damage induces NF-KB-dependent microRNA-21 up-regulation and promotes breast cancer cell invasion. J Biol Chem 2012, 287:21783-21795.

148. Zhang X, Liu S, Hu T, Liu S, He Y, Sun S: Up-regulated microRNA-143 transcribed by nuclear factor kappa B enhances hepatocarcinoma metastasis by repressing fibronectin expression. Hepatology 2009, 50:490-499.

149. Taganov KD, Boldin MP, Chang K-J, Baltimore D: NF-kappaB-dependent induction of microRNA miR-146, an inhibitor targeted to signaling proteins of innate immune responses. Proc Natl Acad Sci USA 2006, 103:12481-12486.

150. Scisciani C, Vossio S, Guerrieri F, Schinzari V, De Laco R, D'Onorio De Meo P. Cervello M, Montalto G, Pollicino T, Raimondo G, Levrero M, Pediconi N: Transcriptional regulation of miR-224 upregulated in human HCCs by NFKB inflammatory pathways. J Hepatol 2012, 56:855-861.

151. Iliopoulos D, Hirsch HA, Struhl K: An epigenetic switch involving NF-\&kappa;B, Lin28, Let-7 MicroRNA, and IL6 links inflammation to cell transformation. Cell 2009, 139:693-706.

152. Li T, Morgan MJ, Choksi S, Zhang Y, Kim Y-S, Liu Z-G: MicroRNAs modulate the noncanonical transcription factor NF-kappaB pathway by regulating expression of the kinase IKKalpha during macrophage differentiation. Nat Immunol 2010, 11:799-805.

153. Zhang S, Shan C, Kong G, Du Y, Ye L, Zhang X: MicroRNA-520e suppresses growth of hepatoma cells by targeting the NF-KB-inducing kinase (NIK). Oncogene 2012, 31:3607-3620.

154. Ahn D-W, Seo JK, Lee SH, Hwang J-H, Lee JK, Ryu JK, Kim Y-T, Yoon YB: Enhanced antitumor effect of combination therapy with gemcitabine and guggulsterone in pancreatic cancer. Pancreas 2012, 41:1048-1057.

155. Walsby E, Pearce L, Burnett AK, Fegan C, Pepper C: The Hsp90 inhibitor NVP-AUY922-AG inhibits NF-KB signaling, overcomes microenvironmental cytoprotection and is highly synergistic with fludarabine in primary CLL cells. Oncotarget 2012, 3:525-534.

156. Buontempo F, Chiarini F, Bressanin D, Tabellini G, Melchionda F, Pession A, Fini M, Neri LM, McCubrey JA, Martelli AM: Activity of the selective IKB kinase inhibitor BMS-345541 against T-cell acute lymphoblastic leukemia: involvement of FOXO3a. Cell Cycle 2012, 11:2467-2475.

157. Salem K, Brown CO, Schibler J, Goel A: Combination chemotherapy increases cytotoxicity of multiple myeloma cells by modification of nuclear factor (NF)-kB activity. Exp Hematol 2013, 41:209-218.

158. Abaza MSI, Bahman AM, Al-Attiyah RJ, Kollamparambil AM: Synergistic induction of apoptosis and chemosensitization of human colorectal cancer cells by histone deacetylase inhibitor, scriptaid, and proteasome inhibitors: potential mechanisms of action. Tumour Biol 2012, 33:1951-1972.

159. Rushworth SA, Bowles KM, Barrera LN, Murray MY, Zaitseva L, MacEwan DJ: BTK inhibitor ibrutinib is cytotoxic to myeloma and potently enhances bortezomib and lenalidomide activities through NF-KB. Cell Signal 2013, 25:106-112.

160. Jiang X-J, Huang K-K, Yang M, Qiao L, Wang Q, Ye J-Y, Zhou H-S, Yi Z-S, Wu F-Q, Wang Z-X, Zhao Q-X, Meng F-Y: Synergistic effect of panobinostat and bortezomib on chemoresistant acute myelogenous leukemia cells via AKT and NF-KB pathways. Cancer Letters 2012, 326:135-142.

161. Prasad S, Yadav VR, Sung B, Reuter S, Kannappan R, Deorukhkar A, Diagaradjane P, Wei C, Baladandayuthapani V, Krishnan S, Guha S, Aggarwal BB: Ursolic acid inhibits growth and metastasis of human colorectal cancer in an orthotopic nude mouse model by targeting multiple cell signaling pathways: chemosensitization with capecitabine. Clin Cancer Res 2012, 18:4942-4953.

162. Fabre C, Mimura N, Bobb K, Kong S-Y, Gorgun G, Cirstea D, Hu Y, Minami J, Ohguchi H, Zhang J, Meshulam J, Carrasco RD, Tai Y-T, Richardson PG, Hideshima T, Anderson KC: Dual inhibition of canonical and noncanonical $\mathrm{NF}-\mathrm{KB}$ pathways demonstrates significant antitumor activities in multiple myeloma. Clin Cancer Res 2012, 18:4669-4681.
163. Kunnumakkara $A B$, Anand $P$, Aggarwal BB: Curcumin inhibits proliferation, invasion, angiogenesis and metastasis of different cancers through interaction with multiple cell signaling proteins. Cancer Letters 2008, 269:199-225.

164. Katsman A, Umezawa K, Bonavida B: Chemosensitization and immunosensitization of resistant cancer cells to apoptosis and inhibition of metastasis by the specific NF-kappaB inhibitor DHMEQ. Curr Pharm Des 2009, 15:792-808.

165. Fuchs O: Transcription factor NF-kB inhibitors as single therapeutic agents or in combination with classical chemotherapeutic agents for the treatment of hematologic malignancies. Curr Mol Pharmacol 2010, 3:98-122.

166. Oiso S, Ikeda R, Nakamura K, Takeda Y, Akiyama S-I, Kariyazono H: Involvement of NF-KB activation in the cisplatin resistance of human epidermoid carcinoma KCP-4 cells. Oncol Rep 2012, 28:27-32.

167. McConkey DJ, Zhu K: Mechanisms of proteasome inhibitor action and resistance in cancer. Drug Resist Updat 2008, 11:164-179.

168. Kozakai N, Kikuchi E, Hasegawa M, Suzuki E, Ide H, Miyajima A, Horiguchi Y, Nakashima J, Umezawa K, Shigematsu N, Oya M: Enhancement of radiosensitivity by a unique novel NF-KB inhibitor, DHMEQ, in prostate cancer. Br J Cancer 2012, 107:652-657.

doi:10.1186/1476-4598-12-86

Cite this article as: Hoesel and Schmid: The complexity of NF-KB signaling in inflammation and cancer. Molecular Cancer 2013 12:86.

\section{Submit your next manuscript to BioMed Central and take full advantage of:}

- Convenient online submission

- Thorough peer review

- No space constraints or color figure charges

- Immediate publication on acceptance

- Inclusion in PubMed, CAS, Scopus and Google Scholar

- Research which is freely available for redistribution 